\title{
Edukasi peningkatan kesadaran preventif terhadap penyakit insomnia pada generasi milenial selama masa pandemi Covid-19
}

\author{
Septi Purnamasari ${ }^{1^{*}}$, Arwan Bin Laeto ${ }^{2}$, Rara Inggarsih³ ${ }^{3}$ Masayu Farah Diba ${ }^{4}$ \\ Program Studi pendidikan Dokter, Fakultas Kedokteran, Universitas Sriwijaya \\ E-mail: septipurnamasari@fk.unsri.ac.id
}

\begin{abstract}
Abstrak
Insomnia merupakan keluhan dalam hal kesulitan untuk memulai atau mempertahankan tidur atau tidur restoratif yang berlangsung setidaknya satu bulan dan menyebabkan gangguan dalam fungsi individu. Pola tidur buruk remaja juga dapat disebabkan oleh penggunaan media elektronik (televisi, laptop, gadget, komputer dan lain sebagainya) untuk durasi yang lama, penyakit migrain, dan merokok. Dampak kekurangan tidur pada remaja dapat mengakibatkan penurunan prestasi akademis sekolah, meningkatkan angka ketidakhadiran di sekolah, depresi dan kecelakaan lalu lintas. Kegiatan pengabdian pada masyarakat ini berupa penyuluhan dan edukasi yang bertujuan untuk meningkatkan pengetahuan siswa-siswi tentang penyakit insomnia yang meliputi gejala umum insomnia, faktor resiko, dampak buruk yang dapat dialami, dan upaya preventif dan promotif terhadap penyakit insomnia. Kegiatan edukasi ini diikuti sebanyak 30 orang siswa-siswi SMP IT Bina Ilmi Palembang. Hasi dari kegiatan edukasi ini didapatkan bahwa terjadi peningkatan pengetahuan siswa-siswi terhadap penyakit insomnia dengan ditunjukkan nilai rata-rata pretest $51,6 \%$ dan rata-rata posttest $80 \%$. Dapat disimpulkan bahwa terjadi peningkatan pengetahuan siswa-siswi terhadap penyakit insomnia. Diharapkan kegiatan pengabdian masyarakat ini dapat dilaksanakan berkesinambungan dengan pemberian materi-materi kesehatan yang lain.
\end{abstract}

Kata kunci: Insomnia, Kualitas Tidur, Edukasi dan Penyuluhan.

\begin{abstract}
Education to increase preventive awareness of insomnia in the millennial generation during the Covid-19 pandemic. Insomnia is a complaint in terms of difficulty initiating or maintaining or restorative sleep that lasts at least one month and causes impairment in the functioning of the individual. Adolescent poor sleep patterns can also be caused by using electronic media (television, laptop, gadgets, computers, etc.) for a long duration, migraine disease, and smoking. The impact of sleep deprivation on adolescents can result in a decrease in school academic achievement, increase absenteeism from school, accidents, and traffic accidents. This community service activity is in the form of counseling and education which aims to increase students' knowledge about insomnia, which includes common symptoms of insomnia, risk factors, adverse effects that can help, and preventive and promotive efforts against insomnia. This educational activity was attended by 30 students of SMP IT Bina Ilmi Palembang. The result of this educational activity was that the increase in students' knowledge of insomnia was shown by an average pretest score of $51.6 \%$ and an average posttest of $80 \%$. It can be summarized that the increase in students' knowledge of insomnia. It is hoped that this community service activity can be carried out continuously by presenting other health materials.
\end{abstract}

Keywords: Insomnia, Sleep Quality, Education and Counseling. 


\section{PENDAHULUAN}

Pandemi Covid-19 merupakan krisis kesehatan yang melanda seluruh negara di dunia termasuk Indonesia. Fenomena ini menyebabkan perubahan yang signifikan pada kehid upan rutinitas kelompok masyarakat termasuk generasi milenial yang meliputi perubahan tingkat aktivitas fisik, pola makan dan kualitas tidur. ${ }^{1}$ Perubahan pada aspek pendidikan dari pembelajaran tatap muka menjadi pembelajaran daring ditambah pemberian kuota internet gratis pada siswa, yang dapat disalahgunakan untuk mengakses internet pada jam tidur malam, mampu menjadi faktor risiko penurunan derajat sehat terutama kualitas tidur buruk, sehingga berpotensi munculnya penyakit insomnia.

Pola tidur buruk remaja juga dapat disebabkan oleh penggunaan media elektronik (televisi, laptop, gadget, komputer dan lain sebagainya) untuk durasi yang lama, penyakit migren, dan merokok. ${ }^{2}$ Insomnia yang disebabkan oleh stres, secara fisiologi mengakibatkan peningkatan kadar kortisol yang kemudian menyebabkan gangguan fisik berupa nyeri otot, rasa lelah dan hipertensi. ${ }^{3}$ Selain itu, insomnia menimbulkan efek psikologi dapat berupa gangguan konsentrasi, kehilangan motivasi, gangguan memori dan depresi pada remaja khususnya. Insomnia dapat menjadi salah gejala yang timbul saat remaja wanita mengalami dismenorea primer. Sehingga, langkah preventif sangat diperlukan agar tidak menjadi penyakit insomnia yang adaptif.

Kegiatan ini dilakukan secara virtual menggunakan media zoom dengan pusat kontrol pelaksanaan edukasi virtual bertempat di ruang bagian Biologi Kedokteran Fakultas Kedokteran Universitas Sriwijaya. Berdasarkan data yang diperoleh dari Kepala Sekolah SMP Islam Terpadu (IT) Bina Ilmi Palembang, diketahui jumlah siswa sebanyak 112 siswa, dengan jumlah laki laki sebanyak 48 orang, sedangkan jumlah perempuan berjumlah 64 orang. Berdasarkan informasi yang didapatkan dari pihak sekolah diketahui sebagian besar siswa jarang mendapatkan informasi dan ilmu pengetahuan lebih terkait penyakit insomnia sehingga deteksi dini penyakit insomnia melalui pengukuran kualitas tidur pada siswa tidak pernah terlaksana dengan baik. 
Kegiatan ini diharapkan dapat meningkatkan kesadaran siswa di SMP IT Bina Ilmi Palembang agar mampu mengenali secara dini gejala umum penyakit insomnia, faktor risiko berikut komplikasi, upaya preventif dan promotif serta peningkatan kesadaran untuk melakukan pemeriksaan kesehatan secara mandiri maupun berkonsultasi kepada tenaga kesehatan secara berkala.

\section{TINJAUAN PUSTAKA}

Tidur merupakan suatu keadaan tak sadar yang masih dapat dibangunkan dengan pemberian rangsang sensorik ataupun rangsangan lain. ${ }^{4}$ Beberapa ahli berpendapat bahwa tidur diyakini dapat memulihkan tenaga karena tidur memberikan waktu untuk perbaikan dan penyembuhan sistem tubuh untuk periode keterjagaan berikutnya. Siklus tidur terdiri dari Rapid Eye Movement (REM) dan tipe Non Rapid Eye Movement (NREM). Fase awal tidur didahului oleh fase NREM yang terdiri dari 4 stadium, lalu dikuti oleh fase REM. Keadaan tidur normal antara fase NREM dan REM terjadi secara bergantian antara 4-6 kali siklus semalam. Tidur NREM yang meliputi 75\% dari keseluruhan waktu tidur sedangkan tidur REM meliputi 25\% dari keseluruhan waktu tidur.

Insomnia sendiri didefinisikan sebagai keluhan dalam hal kesulitan untuk memulai atau mempertahankan tidur atau tidur non-restoratif yang berlangsung setidaknya satu bulan dan menyebabkan gangguan signifikan atau gangguan dalam fungsi individu. Insomnia merupakan gangguan tidur yang paling sering ditemukan. Setiap tahun di dunia, diperkirakan sekitar $20-50 \%$ orang dewasa melaporkan adanya gangguan tidur yang serius. ${ }^{5}$

Berdasarkan laporan Rimbawan (2016), insomnia juga dapat dialami oleh kelompok remaja, khususnya siswa sekolah. Insomnia pada remaja dapat berupa insomnia ringan $(47,6 \%)$, insomnia sedang $(47,6 \%)$ dan insomnia berat $(4,8 \%) .{ }^{6}$ Natalita $(2011)$ menyatakan bahwa dampak kekurangan tidur yang kemudian menyababkan penyakit insomnia pada 
remaja dapat menyebabkan penurunan prestasi akademis sekolah, meningkatkan angka ketidakhadiran di sekolah, depresi dan kecelakaan lalu lintas. ${ }^{7}$

Selain itu, insomnia akibat kualitas tidur yang buruk dapat mempengaruhi fisiologis reproduksi wanita seperti siklus menstruasi. ${ }^{8}$ Kualitas tidur yang buruk dapat menghambat produksi melatonin. Hormon melatonin berfungsi menghambat produksi steroid dengan cara menurunkan ekspresi Steroidgenic Acute Regulatory (StAR), P440 side chain cleavage (P450 scc), 3 $\beta$-Hydroxysteroid Dehydrogenase (17 $\beta$-HSD) yang merupakan protein dan enzim steroidgenik yang penting dalam produksi cyclic adenosine monophosphate (cAMP) dan steroid terutama estrogen yang merupakan hormon pengatur siklus menstruasi.

Insomnia akibat kualitas tidur yang buruk dapat diperbaiki dengan beberapa upaya, salah satunya adalah melalui aktivitas fisik atau olahraga. U.S. Department of Health and Human Services (2008) menginformasikan bahwa olahraga yang dilakukan secara baik dan benar dapat memberi manfaat berupa peningkatan kualitas tidur. Olahraga tersebut adalah olahraga yang dilakukan sekurang-kurangnya 3 kali dalam seminggu dengan durasi olahraga minimal 10 menit/sesi dan seyogyanya dapat mencapai 150 menit dalam seminggu. ${ }^{9}$

\section{METODE}

Khalayak yang menjadi sasaran dalam kegiatan ini adalah generasi milenial laki-laki dan perempuan, yakni siswa-siswi kelas VII SMP IT Bina Ilmi Palembang berjumlah 30 orang. Siswa-siswi yang mengikuti kegiatan edukasi ini terdiri dari 10 orang siswa laki-laki dan 20 orang siswi perempuan. Kegiatan pengabdian masyarakat dalam hal ini berupa edukasi upaya preventif penyakit insomnia yang diawali kualitas tidur buruk selama masa pandemi Covid-19, pendampingan analisis mandiri kualitas tidur dan diskusi serta tanya melalui model presentasi dan pembimbingan secara daring mengggunakan media zoom.

Metode kegiatan yang telah dilakukan melalui tiga tahapan yaitu edukasi kesehatan dan pemberian leaflet, skrining dini dan demonstrasi, dan pemantauan. Edukasi kesehatan dilakukan dengan pemberian informasi melalui ceramah, diskusi dan tanya jawab antara siswa dan 
pemateri serta pemberian leaflet kepada siswa tentang gejala umum penyakit insomnia, faktor risiko, komplikasi, informasi kesehatan mengenai gaya hidup yang sehat, pola makan dan pola tidur yang benar sebagai salah satu cara upaya preventif dan promotif agar terhindar dari gejala insomnia.

Skrining dini dan demonstrasi dilakukan dengan dengan pengisian kuesioner kualitas tidur menggunakan google form dan dilanjutkan dengan tanya jawab pola tidur yang sehat. Pemantauan dilakukan untuk mengetahui keberhasilan dari kegiatan yang telah dilaksanakan oleh dosen dan mahasiswa.

\section{HASIL DAN PEMBAHASAN}

Sebanyak 30 siswa-siswi kelas VII SMP IT Bina Ilmi Palembang mengikuti kegiatan pengabdian masyarakat ini, terdiri dari 20 orang siswi perempuan dan 10 orang siswa lakilaki. Pada kegiatan edukasi yang dilakukan secara virtual, dapat terlihat siswa yang hadir memiliki semangat yang tinggi ditandai beberapa siswa yang bergabung ke media zoom lebih awal dari jadwal yang ditetapkan dan aktif mengajukan pertanyaan terkait subtopiksubtopik edukasi yang disampaikan pemateri maupun masalah kesehatan yang dialami siswa serta cara sederhana menanganinya. Hasil dari kegiatan edukasi ini dapat terlihat dari adanya peningkatan pengetahuan siswa-siswi melalui rata-rata nilai pretest dan posttest yang diberikan. Rata-rata nilai pretest didapatkan yaitu 51,6 dan rata-rata nilai posttest yaitu 80.

Tabel 1. Karakteristik Sosiodemografi

\begin{tabular}{lc}
\hline Variabel & \\
\hline Jenis Kelamin & $10(33,3 \%)$ \\
$\quad$ Laki-laki (n,\%) & $20(66,6 \%)$ \\
$\quad$ Perempuan $(\mathrm{n}, \%)$ & \\
& \\
Pengetahuan tentang insomnia & 51,6 \\
$\quad$ Pretest $(\Sigma)$ & 80 \\
$\quad$ Posttest $(\Sigma)$ & \\
\hline
\end{tabular}

Pada kegiatan ini sebelum dilakukan edukasi, terlebih dahulu diberikan pretest untuk melihat pemahaman para siswa siswi tentang insomnia. Setelah dilakukan pretest kemudian 
diberikan edukasi secara virtual tentang insomnia yang meliputi gejala umum insomnia, faktor risiko, komplikasi serta gaya hidup yang benar agar terhindar dari gejala insomnia. Banyak faktor yang dapat mempengaruhi kualitas dan kuantitas tidur seseorang, diantaranya pola makan, pola hidup sedentari dan durasi screen-time. Beberapa riset dilaporkan bahwa durasi screen-time yang lebih dari 2 jam/hari berpotensi menyebabkan gangguan tidur berupa memendeknya durasi tidur dan melambatnya onset tidur. 10,11

Pada kegiatan pengabdian ini, siswa diberi edukasi tentang pentingnya melakukan aktivitas fisik pada kondisi pandemi. Edukasi ini diharapkan agar para siswa siswi tetap mempertahankan kesehatan dan mampu mencegah penyakit insomnia. Penyakit insomnia akibat kualitas tidur yang buruk juga dapat disebabkan oleh kurangnya aktivitas fisik, seperti olahraga khususnya selama pandemi Covid-19 ini. Xiang et al. (2020) melaporkan bahwa telah terjadi pengurangan aktivitas fisik di kalangan remaja dari 21,3\% menjadi 65,6\%. ${ }^{12}$ Selain itu, penelitian di Spanyol yang diukur secara subjektif menunjukkan bahwa terjadi penurunan aktivitas fisik yang signifikan dan perilaku sedentari justru meningkat signifikan. ${ }^{13}$

Olahraga rutin yang dilakukan selama 30-45 menit selama 3 kali seminggu pada intensitas ringan hingga sedang mampu mempertahankan kesehatan dan membantu kualitas dan kuantitas tidur yang baik. Olahraga yang dilakukan dapat memberi efek pada kualitas tidur seseorang, baik yang bersifat akut maupun kronik. Efek akut dari aktivitas fisik yang dilakukan dapat menstimulasi kelelahan sistem saraf pusat, peningkatan suhu tubuh inti dan perubahan detak jantung. Keadaan ini kemudian meningkatkan sekresi GABA pada hipotalamus anterior, yang akhirnya meningkatkan modulasi vagal pengontrol sistem parasimpatis sehingga menyebabkan perbaikan kualitas tidur. ${ }^{14}$ Efek kronis aktivitas fisik dapat menyebabkan perubahan sekresi hormon pertumbuhan (GH) dan faktor neurotropik, seperti Brain-derived neurotrophic factor (BDNF). Peningkatan sekresi (GH) saat tidur kemudian mempengaruhi tidur gelombang lambat sehingga memperbaiki kualitas tidur. Selain itu, olahraga juga mampu meningkatkan fungsi kognitif melalui efek 
kronis yang ditandai dengan meningkatnya sekresi BNDF, yang juga dikenal sebagai faktor yang berperan penting dalam plastisitas dan proses belajar. ${ }^{15}$

Salah satu upaya untuk memperbaiki kualitas tidur yang buruk adalah selalu mengendalikan stres. Pengendalian stres dapat berupa peningkatan imunitas fisik dan peningkatan kesehatan jiwa serta psikososial. Pada kegiatan edukasi ini juga dilakukan skrining kualitas tidur siswa yang diukur secara subjektif menggunakan instrumen kuesioner melalui google form. Bila hasil pengukuran menunjukkan tanda-tanda umum penyakit insomnia melalui kriteria kualitas tidur yang buruk, maka siswa dianjurkan untuk membatasi makanan terlalu banyak pada waktu malam, mengurangi konsumsi makanan junk food, tidak mengkonsumsi kafein, mengatur jam tidur, melakukan olah raga secara teratur menghindari rokok dan alkohol dan berupaya untuk selalu mengendalikan stres.

Dalam upaya pengendalian dan efek stres selama masa pandemi Covid-19, untuk meningkatkan imunitas fisik, siswa disarankan untuk mengkonsumsi makanan seimbang, minum air secara cukup (2 liter per hari), olahraga minimal 30 menit, berjemur di pagi hari (seminggu 2 kali) dan benar-benar menghindari rokok dan alkohol. Sedangkan peningkatan kondisi kesehatan jiwa dan psikososial dapat dilakukan dengan cara menghadirkan emosi positif dan pikiran positif seperti rasa gembira, melakukan hobi yang disukai, menjauhi informasi hoax, positive self-talk, responsif terhadap kejadian sekitar dan mengenang hanya pengalaman yang menyenangkan serta selalu yakin bahwa pandemi akan segera teratasi.

Pada akhir kegiatan para siswa memberikan tanggapannya sehubungan dengan kegiatan yang telah berlangsung. Mereka sangat senang dengan diselenggarakannya kegiatan edukasi ini karena dapat meningkatkan pengetahuan serta kesadaran akan pentingnya menjaga kesehatan dan rutin memeriksakan kondisi kesehatan guna mencegah penyakit insomnia. Selanjutnya dilakukan posttest untuk mengukur peningkatan pengetahuan remaja setelah diberikan edukasi secara virtual dan hasilnya menunjukkan peningkatan nilai rara-rata yang baik dibandingkan saat pretest. Kegiatan ditutup dengan 
pemberian cinderamata sebagai kenang-kenangan kepada peserta dan juga beberapa alat kesehatan seperti alat periksa tekanan darah digital, masker dan hand sanitezer ditinggalkan untuk keperluan siswa dan guru dalam upaya tetap menjaga kesehatan selama masa pandemi.

\section{SIMPULAN}

Kegiatan pengabdian pada masyarakat pada siswa Sekolah Menengah Pertama Islam Terpadu (SMP-IT) Bina Ilmi Palembang melalui media Zoom telah menambah wawasan dan pengetahuan siswa tentang penyakit insomnia meliputi gejala umum, faktor risiko, komplikasi, upaya promotif dan preventif yang dapat dilakukan serta meningkatkan kesadaran untuk rutin melakukan pemeriksaan mandiri dan pemeriksaan ke fasilitas pelayanan kesehatan terdekat.

\section{Ucapan Terima Kasih}

Penulis mengucapkan banyak terima kasih sebesar-besarnya kepada semua pihak yang telah membantu dalam kegiatan pengabdian ini sehingga dapat terlaksana dengan baik, terutama kepada Rektor Universitas Sriwijaya, Ketua Pusat Pelayanan dan Pengembangan Lembaga Penelitian dan Pengabdian (PPP-LPPM) UNSRI, Dekan FK UNSRI, SMP IT Bina Ilmi Palembang. Terima kasih juga kepada Fakultas Kedokteran Universitas Sriwijaya yang telah mendanai pelaksanaan kegiatan pengabdian masyarakat ini sesuai dengan Surat Perjanjian Pelaksanaan Kegiatan Pengabdian Kepada Masyarakat Fakultas Kedokteran Universitas Sriwijaya Nomor: 86/013/UN9.1.4/PLP-PPM/PL/X/2020, 6 November 2020.

\section{Referensi}

1. Zeller M Van, Amorim P, Pimentel A. Since January 2020 Elsevier has created a COVID19 resource centre with free information in English and Mandarin on the novel coronavirus COVID- 19 . The COVID-19 resource centre is hosted on Elsevier Connect, the company' s public news and information . 2020;(January).

2. Hepilita Y, Gentas AA. Hubungan Durasi Penggunaan Media Sosial Dengan Gangguan Pola Tidur Pada Anak Usia 12 Sampai 14 Tahun Di SMP Negeri 1 Langke Rembang. J Wawasan Kesehat. 2018;3(2):78-87. 
3. Van Cauter E, Balbo M, Leproult R. Impact of sleep and its disturbances on hypothalamo-pituitary-adrenal axis activity. Int $J$ Endocrinol. 2010;2010. doi:10.1155/2010/759234

4. Hall JE, Arthur C G. Buku Ajar Fisiologi Kedokteran. Edisi 12. Singapore: Saunders; 2014.

5. Kaplan HI, Sadock BJ, Grebb JA. Sinopsis Psikiatri Ilmu Pengetahuan Perilaku Psikiatri Klinis Jilid Satu. Jakarta: Binarupa Aksara Publisher; 2010.

6. Rimbawan P, Ratep N. Prevalensi Dan Korelasi Insomnia Terhadap Kemampuan Kognitif Remaja Usia 15-18 Tahun Di Panti Asuhan Widhya Asih 1 Denpasar. E-Jurnal Med Udayana. 2016;5(5):1-8.

7. Natalita C, Sekartini R, Poesponegoro H. Skala Gangguan Tidur untuk Anak (SDSC) sebagai Instrumen Skrining Gangguan Tidur pada Anak Sekolah Lanjutan Tingkat Pertama. Sari Pediatr. 2016;12(6):365. doi:10.14238/sp12.6.2011.365-72

8. Deaneva AM, Hidayati RS, Sumardiyono. Hubungan Kualitas Tidur terhadap Siklus Menstruasi pada Dokter. Nexus Kedokt Komunitas. 2015;4(2):59-69.

9. Saputri KR, Suryawan A. Hubungan Olahraga Dengan Kualitas Tidur Satpam Bank Di Daerah Surakarta. Fak Kedokt UNS. 2015;4(2):28-35.

10. Kedokteran F, Sam U, Kepel BJ. Hubungan Kejadian Insomnia Dengan Konsentrasi Belajar Pada Mahasiswa Semester V Program Studi Ilmu Keperawatan Fakultas Kedokteran Universitas Sam Ratulangi. J Keperawatan. 2018;6(1).

11. Istiqomah SN, Lisiswanti R. Dampak Eksposur Layar Monitor Terhadap Gangguan Tidur Dan Tingkat Obesitas Pada Anak Anak The Effect of Screen Time Exposure in Sleep Disorder and Obesity Level on Children. Majority. 2017;6(2):72-77.

12. Xiang $M$, Zhang Z, Kuwahara K. Impact of COVID-19 pandemic on children and adolescents' lifestyle behavior larger than expected. Prog Cardiovasc Dis. 2020;63(4):531532. doi:10.1016/j.pcad.2020.04.013

13. Sañudo B, Fennell C, Sánchez-Oliver AJ. Objectively-assessed physical activity, sedentary behavior, smartphone use, and sleep patterns preand during-COVID-19 quarantine in young adults from Spain. Sustain. 2020;12(15):1-12. doi:10.3390/SU12155890

14. Uchida S, Shioda K, Morita Y, Kubota C, Ganeko M, Takeda N. Exercise effects on sleep physiology. Front Neurol. 2012;APR(April):1-5. doi:10.3389/fneur.2012.00048

15. Wahyuni N, Satria Nugraha MH, Juhanna IV. Olahraga Dapat Meningkatkan Fungsi Kognitif Melalui Modulasi Epigenetik Ekspresi Gen Brain-Derived Neurotrophic Factor (Bdnf). Sport Fit J. 2019:24-30. doi:10.24843/spj.2018.v06.i03.p04 